\title{
Unusual Iron Nitride Formation Upon Nitriding Fe-Si Alloy
}

\author{
S.R. MEKA, A. SCHUBERT, E. BISCHOFF, and E.J. MITTEMEIJER
}

The influence of $\mathrm{Si}$, substitutionally dissolved in ferritic $\mathrm{Fe}-2$ at. pct $\mathrm{Si}$ and $\mathrm{Fe}-4.5$ at. pct $\mathrm{Si}$ alloys, on the nucleation and growth of $\gamma^{\prime}$ iron nitride upon controlled gaseous nitriding was investigated. The nitrided specimens were characterized by XRD, light microscopy, TEM, EELS, EPMA and EBSD. The combination of difficult and thus delayed precipitation of (1) silicon nitride, because of a large misfit with the ferrite matrix, and (2) $\gamma^{\prime}$ iron nitride, because of the negligible solubility of $\mathrm{Si}$, was shown to lead to a series of unusual, nonequilibrium phenomena: high nitrogen supersaturation, development of Si-containing metastable $\gamma^{\prime}$ phase of peculiar morphology, precipitation of amorphous silicon nitride in $\gamma^{\prime}$ and development of $\varepsilon$ nitride at thermodynamic conditions unlikely to allow its formation.

https://doi.org/10.1007/s11661-020-05713-4

(C) The Author(s) 2020

\section{INTRODUCTION}

THE life and serviceability of engineering components can be enhanced by dedicated surface treatments. Nitriding is possibly the most versatile thermochemical surface engineering method among those employed in practice as, by tuned application, it can drastically improve the fatigue, wear and corrosion resistances of engineering components. ${ }^{[1-6]}$ Although this surface treatment method has been widely employed in the industry for the past 100 years, ${ }^{[7]}$ fundamental understanding of the underlying (micro)mechanisms is not complete yet. Therefore, nitriding studies have been performed on relatively simple iron-based binary alloys, especially in recent years. On the one hand, most work has been done on the alloying element nitride precipitation in ferritic substrates (responsible for enhancing the fatigue resistance), $\mathrm{Fe}-\mathrm{Al},{ }^{[8-12]} \mathrm{Fe}-\mathrm{Cr},{ }^{[13,14]}$ $\mathrm{Fe}-\mathrm{Si}^{[15-20]}$ and $\mathrm{Fe}-\mathrm{V},{ }^{[21,22]}$ and ternary alloys, such as $\mathrm{Fe}-\mathrm{Cr}-\mathrm{C},{ }^{[12,23]} \mathrm{Fe}-\mathrm{Cr}-\mathrm{Al},{ }^{[24]}$ Fe-Cr-Ti ${ }^{[25]}$ and

S.R. MEKA is with the Metallurgical and Materials Engineering Department, Indian Institute of Technology Roorkee, Roorkee, 247667, India, and Max Planck Institute for Intelligent Systems, Stuttgart, Germany. Contact e-mail: mekafmt@iitr.ac.in A. SCHUBERT is with the Institute for Materials Science, University of Stuttgart, Stuttgart, Germany. E. BISCHOFF is with the Max Planck Institute for Intelligent Systems. E.J. MITTEMEIJER is with the Max Planck Institute for Intelligent Systems and also with the Institute for Materials Science, University of Stuttgart.

Manuscript submitted October 30, 2019.

Article published online March 19, 2020
$\mathrm{Fe}-\mathrm{Me}-\mathrm{Si} .^{[26]}$ On the other hand, the effect of alloying elements on the formation of the surface iron nitride $\left(\gamma^{\prime}-\mathrm{Fe}_{4} \mathrm{~N}_{1-x}\right.$ and $\left.\varepsilon-\mathrm{Fe}_{2} \mathrm{~N}_{1-y}\right)$ compound layer, usually indicated as the "white layer" (responsible for improved wear and corrosion resistances), has only recently been investigated. ${ }^{[27]}$ Whereas in the presence of strong nitride-forming alloying elements, such as $\mathrm{Cr}, \mathrm{V}$ and $\mathrm{Ti}$, the usual layer-type growth of iron nitride is observed, ${ }^{[28-30]}$ weak nitride-forming alloying elements, such as $\mathrm{Al}$ and $\mathrm{Mo}$, induce an unusual (e.g., plate-like) morphology of the formed iron nitride. ${ }^{[31-33]}$

Usually steel contains $\mathrm{Si}$ : it is an important de-oxidizer for steel melts and an important alloying element in transformation-induced plasticity (TRIP), bainitic and electrical steels. ${ }^{[34,35]}$ After the first demonstration that silicon nitride precipitates in ferrite in a highly unusual amorphous state, ${ }^{[36]}$ only recently have the kinetics of this amorphous silicon nitride precipitation been investigated more extensively. ${ }^{[18-20,26]}$ It was shown that the precipitation of amorphous silicon nitride in the ferrite matrix takes place only very slowly because of the large volume misfit, which has to be accommodated upon precipitating silicon nitride in the ferrite matrix. Thus, Si is effectively a weak nitride former, ${ }^{[26]}$ although, from a chemical point of view, $\mathrm{Si}$ is a strong nitride-forming element. ${ }^{[37,38]}$ A thermodynamic background for such different nitriding behaviors for different alloying elements is provided by Refs. 39,40. In the literature, detailed information on the influence of $\mathrm{Si}$ on the compound-layer formation is lacking (for example, see Refs. 41-43). Against this background, in this work $\mathrm{Fe}-\mathrm{Si}$ alloys (Fe-2 at. pct $\mathrm{Si}$ and $\mathrm{Fe}-4.5$ at. pct $\mathrm{Si}$ ) were nitrided to gain understanding of the influence of substitutionally dissolved $\mathrm{Si}$ on the nucleation and growth of, in particular $\gamma^{\prime}$, iron nitride. 


\section{EXPERIMENTAL}

\section{A. Specimen Preparation}

Cast rods of Fe-2 at. pct $\mathrm{Si}$ and $\mathrm{Fe}-4.5$ at. pct Si alloys with $10 \mathrm{~mm}$ diameter and $100 \mathrm{~mm}$ length were produced by induction melting of elemental granules of iron (purity: $99.98 \mathrm{wt}$ pct) and pieces of silicon (purity: 99.999 wt pct) under a protective argon atmosphere. The amounts of silicon and light element impurities in the produced casts were analyzed. The silicon content was determined by inductively coupled plasma-optical emission spectroscopy (ICP-OES), the nitrogen and oxygen contents were measured by applying carrier gas hot extraction. Sulfur and carbon contents were determined by the combustion method. The thus obtained results of the chemical analysis are shown in Table I.

A cast rod of $\mathrm{Fe}-2$ at. pct $\mathrm{Si}$ alloy was cut into pieces, which were cold rolled to produce sheets having a thickness of approximately $1 \mathrm{~mm}$. From these sheets, rectangular specimens with lateral dimensions of $10 \mathrm{~mm}$ $\times 15 \mathrm{~mm}$ were cut. The surfaces of the specimens were ground and polished down to $1-\mu \mathrm{m}$ diamond finish. These prepared specimens were placed into a quartz tube, which was evacuated, filled with argon gas, encapsulated and subsequently annealed at $750{ }^{\circ} \mathrm{C}$ $(1023 \mathrm{~K})$ for 2 hours to recrystallize the specimens. ${ }^{[44]}$ Afterwards, the specimens were ultrasonically cleaned in ethanol and subjected to the nitriding treatment.

Attempts to cold roll pieces of the Fe-4.5 at. pct Si alloy were not successful because of cracking of the material while rolling, which is attributed to its extreme brittleness. Therefore, approximately 1-mm-thick specimens were cut directly from the cast rod and prepared (see above) for nitriding. As for the Fe-2 at. pct $\mathrm{Si}$ specimens, the Fe- 4.5 at. pct $\mathrm{Si}$ specimens were subjected to annealing at $750{ }^{\circ} \mathrm{C}(1023 \mathrm{~K})$ for 2 hours in argon to relieve any deformation induced in the specimens during cutting and also to remove any casting-induced elemental segregations.

\section{B. Nitriding}

The specimens were nitrided in a laboratory-scale, vertical quartz tube furnace having an inner diameter of $28 \mathrm{~mm}$, equipped with a facility to hang the specimen in the middle of the furnace and a water-filled flask to quench the specimens after completing the nitriding treatment. The furnace temperature was controlled within $\pm 1 \mathrm{~K}$ variation, and the flow rates of ammonia and hydrogen gases were controlled by MKS mass flow controllers. For the nitriding treatment, high-purity ammonia (99.99 pct) and hydrogen (99.999 pct) gases were used. Before starting, the furnace was purged with nitrogen gas to remove all the oxygen and other adsorbed gases from the furnace walls. After setting the required flow rates of ammonia $(195 \mathrm{ml} / \mathrm{min})$ and hydrogen $(305 \mathrm{ml} / \mathrm{min})$ and allowing the gas mixture to reach a steady-state condition in the furnace, the specimen was hung up in the uniform temperature zone of the furnace. The total gas flow rate of $500 \mathrm{ml} / \mathrm{min}$ resulted in a linear gas velocity of $13.5 \mathrm{~mm} / \mathrm{s}$, at room temperature, for the quartz tube furnace used. At this linear gas velocity, a change of the chemical composition of the gas mixture due to dissociation of ammonia can be neglected. ${ }^{[45]}$ These nitriding conditions result in a nitriding potential, $r_{\mathrm{N}}$, of $0.82 \mathrm{~atm}^{-1 / 2}{ }^{[46]}$ For the applied temperature of $550{ }^{\circ} \mathrm{C}(823 \mathrm{~K})$ and $r_{\mathrm{N}}$, only $\gamma^{\prime}$ iron nitride formation is expected upon nitriding pure iron according to the Lehrer diagram. ${ }^{[4]}$ After completing the nitriding treatment, the specimens were quenched in a water-filled flask. To minimize the risk of specimen surface oxidation during water quenching, before quenching the water in the quenching flask was purged with nitrogen gas for about $20 \mathrm{~min}$ to remove/ minimize the amount of oxygen dissolved in the water. To trace the evolution of the compound layer with time, specimens of both alloys were nitrided for three different times ( $15 \mathrm{~min}, 2$ hours and 20 hours) at $550{ }^{\circ} \mathrm{C}(823 \mathrm{~K})$ and $r_{\mathrm{N}}=0.82 \mathrm{~atm}^{-1 / 2}$.

\section{Specimen Characterization}

\section{Light microscopy}

The nitrided specimens were cut perpendicular to the nitrided surface and hot embedded in Struers PolyFast. To protect the surface regions from spalling and/or rounding off during metallographic preparation of cross sections, the sample surfaces were electroplated with a protective Ni layer. The thus embedded specimens were prepared for metallographic examination by grinding and polishing down to $1-\mu \mathrm{m}$ diamond paste followed by etching with 2 vol pct Nital. Light microscopy investigations were performed on the etched cross sections of the nitrided specimens using a Zeiss Axiophot microscope equipped with a digital camera (Olympus Color View IIIu).

\section{Transmission electron microscopy (TEM)}

The TEM specimens were prepared from the nitrided specimens using a focused ion beam (FIB), employing a FEI Nova Nanolab 600 operated with an accelerating voltage of $30 \mathrm{kV}$ and a current from $30 \mathrm{pA}$ to $20 \mathrm{nA}$.

Table I. Chemical Composition of the Fe-2 At. Pet Si Alloy and Fe-4.5 At. Pet Si Alloy Casts

\begin{tabular}{lllllr}
\hline & \multicolumn{4}{c}{ Content } \\
\cline { 2 - 6 } Alloy & Si (Wt Pct) & Si (At. Pct) & N $(\mu \mathrm{g} / \mathrm{g})$ & $\mathrm{O}(\mu \mathrm{g} / \mathrm{g})$ & $\mathrm{S}(\mu \mathrm{g} / \mathrm{g})$ \\
\hline Fe-2 At. Pct Si & $1.03 \pm 0.02$ & $2.03 \pm 0.04$ & $<5$ & $67 \pm 10$ & $<10$ \\
Fe-4.5 At. Pct Si & $2.32 \pm 0.02$ & $4.51 \pm 0.04$ & $<5$ & $40 \pm 10$ & $<20$ \\
\hline
\end{tabular}


TEM investigations were performed using a Philips CM 200 microscope operating at $200 \mathrm{kV}$, equipped with an energy-dispersive X-ray detection system (EDX). Bright-field (BF) and dark-field (DF) images and the corresponding selected area diffraction patterns (SADPs) were recorded using a Gatan CCD camera attached to the microscope.

For obtaining the elemental composition of the very small nitride precipitates, a Zeiss 912 TEM with an omega energy filter for electron energy loss spectroscopy (EELS) was employed.

\section{Electron probe micro-analysis (EPMA)}

EPMA was performed on the polished cross sections of the nitrided specimens employing a Cameca SX100 microprobe. Measurements were performed using an accelerating voltage of $15 \mathrm{kV}$ and a current of $100 \mathrm{nA}$. For obtaining the elemental contents of $\mathrm{Fe}, \mathrm{Si}$ and $\mathrm{N}$ at each measured point, the intensities of the characteristic $\mathrm{Fe}-\mathrm{K}_{\beta}, \mathrm{Si}-\mathrm{K}_{\alpha}$ and $\mathrm{N}-\mathrm{K}_{\alpha}$ radiations were measured and divided by the corresponding intensities measured from standard specimens of pure iron, silicon and $\gamma^{\prime}-\mathrm{Fe}_{4} \mathrm{~N}$ (for nitrogen). The elemental concentrations then were calculated from these intensity ratios applying the $\phi(\rho z)$ approach. ${ }^{[48]}$

\section{X-ray diffraction ( $X R D)$}

$X$-ray diffractograms were recorded from the surface of the nitrided specimens. XRD measurements were performed with a PANalytical X'pert Multipurpose Diffractometer, which was equipped with a graphite monochromator in the diffracted beam, employing $\mathrm{Co}-\mathrm{K}_{\alpha}$ radiation and Bragg-Brentano geometry. During the measurements, the specimens were rotated around their surface normals to obtain better crystallite statistics. The expected diffraction line positions of the various phases were calculated using the lattice parameter data of various phases presented in the ICDD database. ${ }^{[49]}$

\section{Electron back-scatter diffraction (EBSD)}

For EBSD investigations, strain-free cross sections are prepared as described in Section II-C-1 with additional final polishing using OPS colloidal silica suspension $(0.04 \mu \mathrm{m})$ (Struers GmbH). EBSD measurements were carried out using a Zeiss scanning electron microscope (Leo $438 \mathrm{VP}$ ) operating at $20 \mathrm{kV}$, equipped with an EBSD system (TSL, EDAX) and OIM 5 analyzing software.

a. Analysis of the orientation relationship $\gamma^{\prime}$ iron nitride has a face-centered cubic (FCC) iron sublattice with an ordered occupation of $\mathrm{N}$ on octahedral interstices, such that $\gamma^{\prime}$ has a primitive cubic crystal translation. The ferritic matrix of the $\mathrm{Fe}-\mathrm{Si}$ specimens is body centered cubic (BCC). Orientation relationships (ORs) commonly observed for FCC/BCC systems are ${ }^{[50,51]}$ :
(1) Bain $^{[52]}$
$(001)_{\mathrm{FCC}} / /(0 \overline{1} 1)_{\mathrm{BCC}}$ and $[100]_{\mathrm{FCC}} / /$ $[100]_{\mathrm{BCC}}$

(2) Pitsch $^{[53]}$ (closest packed directions of $\mathrm{BCC}$ and FCC parallel) $(001)_{\mathrm{FCC}} / /(0 \overline{1} 1)_{\mathrm{BCC}}$ and $[110]_{\mathrm{FCC}} / /[111]_{\mathrm{BCC}}$

(3) Nishiyama-Wassermann $(\mathrm{N}-\mathrm{W})^{[54,55]}$ (most densely packed planes of BCC and FCC parallel) $(1 \overline{1} 1)_{\mathrm{FCC}} / /(1 \overline{1} 0)_{\mathrm{BCC}}$ and $[011]_{\mathrm{FCC}} / /[001]_{\mathrm{BCC}}$

(4) Kurdjumov-Sachs $(\mathrm{K}-\mathrm{S})^{[56]}$ (most densely packed planes and closest packed directions of $\mathrm{BCC}$ and FCC parallel $)(1 \overline{1} 1)_{\mathrm{FCC}} / /(1 \overline{1} 0)_{\mathrm{BCC}}$ and $[\overline{1} \overline{1} 0]_{\mathrm{FCC}} / /$ $[\overline{1} \overline{1} \overline{1}]_{\mathrm{BCC}}$

These ORs are interrelated by small rotations around a particular crystallographic axis. A particular OR can be characterized by the angles between the $\langle 100\rangle$ directions of the $\gamma^{\prime}$ precipitate (FCC iron sublattice) and the $\langle 100\rangle$ directions of its surrounding matrix (BCC lattice), which are unique for each type of OR. These angles, as expected for each of the above four commonly observed ORs for FCC/BCC systems, are presented in Table II. Note that the values of the angles between the $\langle 100\rangle$ directions of the precipitate and matrix depend on the variant selected of the OR considered, but the set of values remains unique for each OR, irrespective of the variant selected.

In most cases, the observed OR was found to deviate somewhat from one of the above ideal ones, owing to the development of misfit strain fields around the growing precipitates: the minimization of the misfit strain energy causes the OR to deviate from the ideal rational OR, i.e., irrational ORs occur. ${ }^{[51]}$

From the Euler angles describing the orientation of the grain considered with respect to the specimen cross-sectional frame of reference, as determined by EBSD, values can be derived for the angles between the $\langle 100\rangle$ directions of the precipitates and matrix. Comparing these angular values with the data in Table II allows identification of the occurring OR.

\section{RESULTS AND EVALUATION}

\section{A. X-ray Diffraction: Phase Analysis}

$\mathrm{X}$-ray diffractograms recorded from the surfaces of the un-nitrided and nitrided [for different times at $550{ }^{\circ} \mathrm{C}(823 \mathrm{~K})$ employing a nitriding potential of 0.82 $\mathrm{atm}^{-1 / 2}$ ] Fe-2 at. pct $\mathrm{Si}$ and $\mathrm{Fe}-4.5$ at. pet $\mathrm{Si}$ alloy specimens are shown in Figures 1 and 2, respectively. Evidently, distinct formation of $\gamma^{\prime}$ takes place upon nitriding; the amount of $\gamma^{\prime}$ increases with nitriding time. Although $\varepsilon$ iron nitride formation was not expected for pure iron under the employed nitriding conditions (see the so-called Lehrer diagram ${ }^{[47]}$ ), some $\varepsilon$ nitride developed as well. EBSD investigations confirmed the occurrence of $\varepsilon$ (see Figure 7 in Section III-C).

\section{B. Morphologic Characterization: Light Microscopy}

Light optical micrographs recorded from the cross sections of $\mathrm{Fe}-2$ at. pct $\mathrm{Si}$ alloy specimens nitrided for different times are shown in Figure 3. After $15 \mathrm{~min}$ of nitriding, a thin $\gamma^{\prime}$ layer had formed on the surface with 
Table II. Angles (in Degrees) Between $\langle\mathbf{1 0 0}\rangle$ Directions of Undistorted BCC and FCC Precipitate/Matrix Systems for Commonly Reported Orientation Relationships (ORs)

\begin{tabular}{|c|c|c|c|c|}
\hline Angle Between $\langle 100\rangle_{\mathrm{FCC}}$ and $\langle 100\rangle_{\mathrm{BCC}}$ & $\mathrm{KS}$ & NW & Pitsch & Bain \\
\hline$[001]_{\mathrm{FCC}} \wedge[001]_{\mathrm{BCC}}$ & 48.2 & 45 & 45 & 45 \\
\hline$[001]_{\mathrm{FCC}} \wedge[010]_{\mathrm{BCC}}$ & 137.9 & 135 & 134.2 & 135 \\
\hline$[001]_{\mathrm{FCC}} \wedge[100]_{\mathrm{BCC}}$ & 85.7 & 90 & 83.1 & 90 \\
\hline$[010]_{\mathrm{FCC}} \wedge[001]_{\mathrm{BCC}}$ & 42.1 & 45.8 & 45 & 45 \\
\hline$[010]_{\mathrm{FCC}} \wedge[010]_{\mathrm{BCC}}$ & 49.5 & 45.8 & 45.8 & 45 \\
\hline$[010]_{\mathrm{FCC}} \wedge[100]_{\mathrm{BCC}}$ & 99.6 & 99.7 & 96.9 & 90 \\
\hline$[100]_{\mathrm{FCC}} \wedge[001]_{\mathrm{BCC}}$ & 85.7 & 83.1 & 90 & 90 \\
\hline$[100]_{\mathrm{FCC}} \wedge[010]_{\mathrm{BCC}}$ & 80.4 & 83.1 & 80.3 & 90 \\
\hline$[100]_{\mathrm{FCC}} \wedge[100]_{\mathrm{BCC}}$ & 10.5 & 9.7 & 9.7 & 0 \\
\hline
\end{tabular}

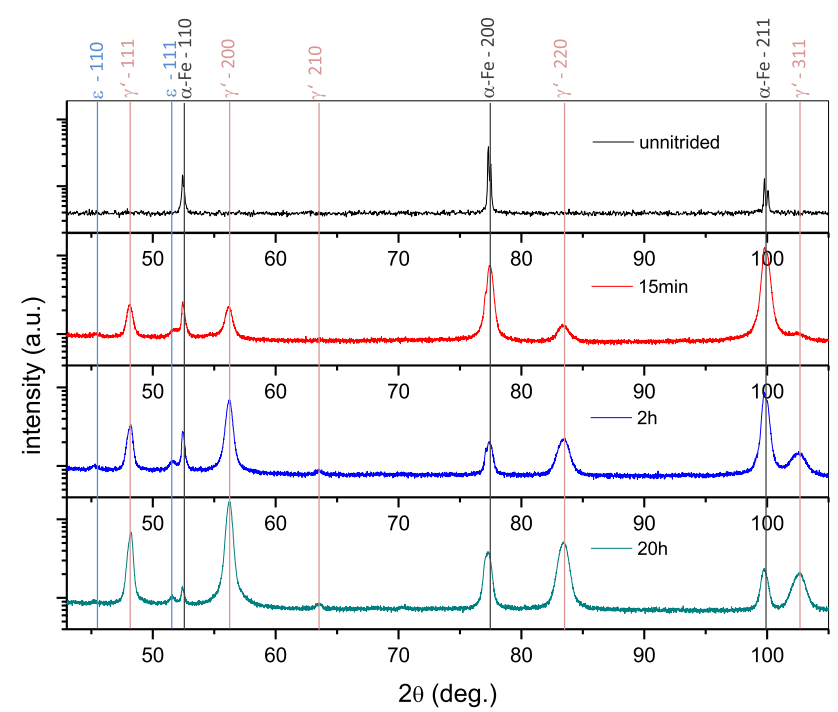

Fig. 1-XRD patterns recorded from the surface of un-nitrided and nitrided $\left[550{ }^{\circ} \mathrm{C}(823 \mathrm{~K}), r_{\mathrm{N}}=0.82 \mathrm{~atm}^{-1 / 2}\right] \mathrm{Fe}-2$ at. pct $\mathrm{Si}$ alloy specimens. Nitriding times are indicated in the figure.

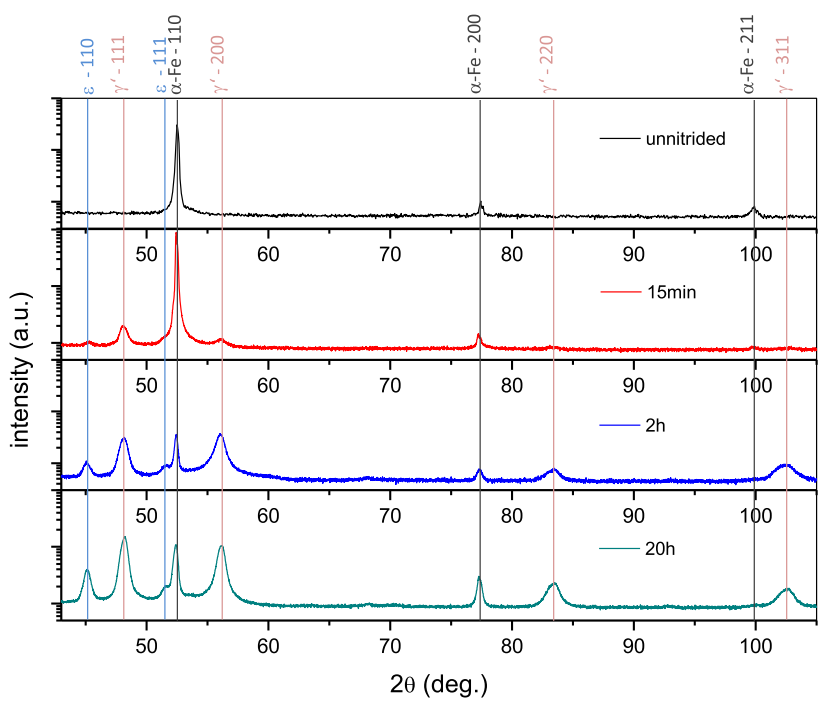

Fig. 2-XRD patterns recorded from the surface of the un-nitrided and nitrided $\left[550{ }^{\circ} \mathrm{C}(823 \mathrm{~K}), r_{\mathrm{N}}=0.82 \mathrm{~atm}^{-1 / 2}\right] \mathrm{Fe}-4.5$ at. pct $\mathrm{Si}$ alloy specimens. Nitriding times are indicated in the figure.

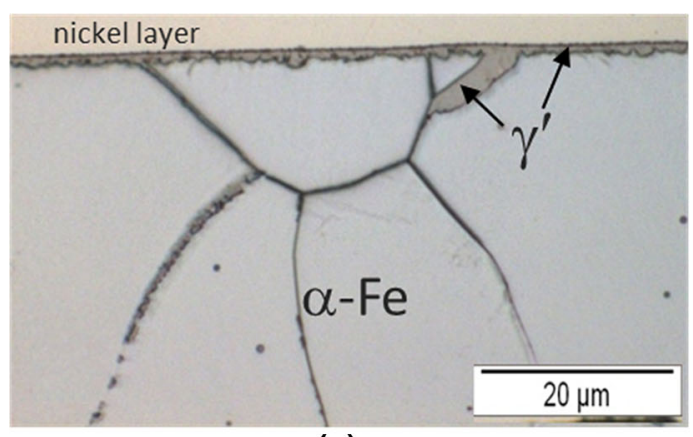

(a)

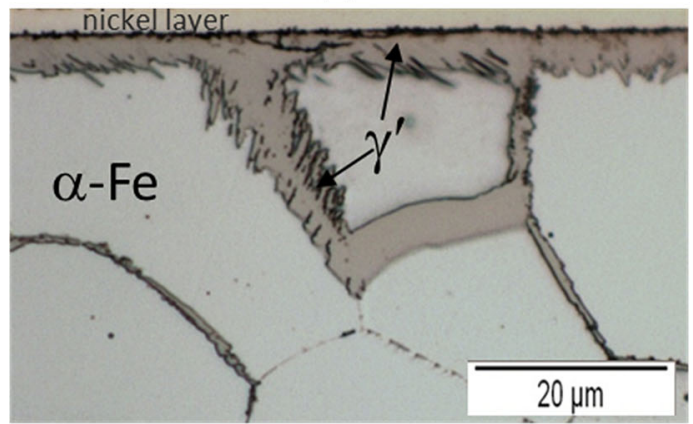

(b)

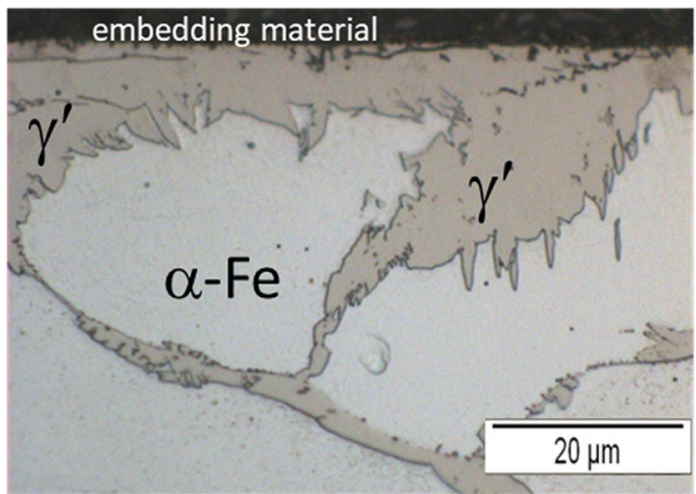

(c)

Fig. 3-Light optical micrographs recorded from cross sections of $\mathrm{Fe}-2$ at. pct $\mathrm{Si}$ alloy specimens nitrided at $550^{\circ} \mathrm{C}(823 \mathrm{~K})$ and $r_{\mathrm{N}}=$ $0.82 \mathrm{~atm}^{-1 / 2}$ for (a) $15 \mathrm{~min},(b) 2 \mathrm{~h}$ and (c) $20 \mathrm{~h}$. 


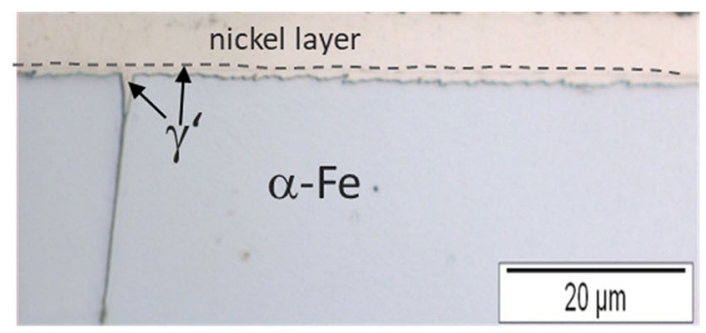

(a)

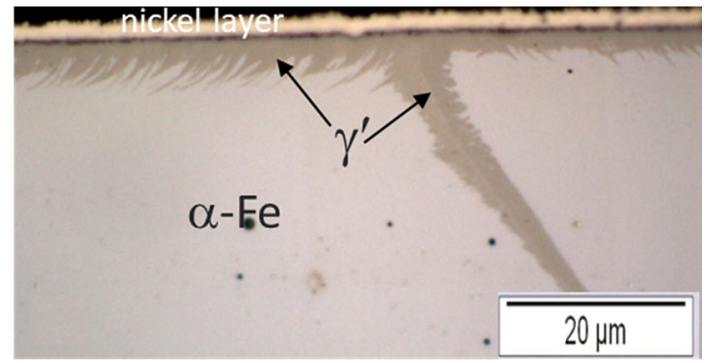

(b)

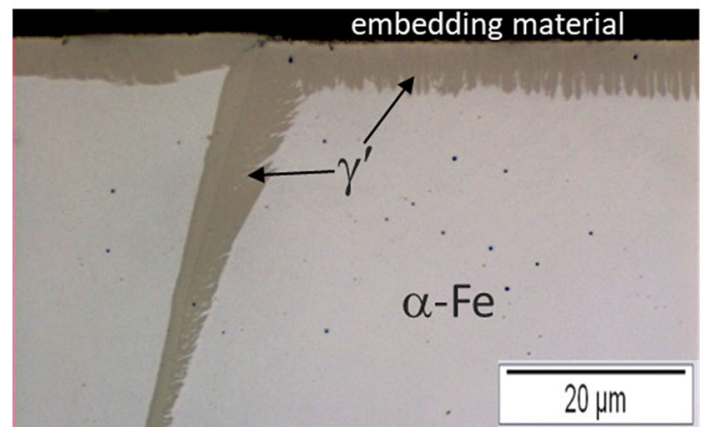

(c)

Fig. 4-Light optical micrographs recorded from cross sections of $\mathrm{Fe}-4.5$ at. pet $\mathrm{Si}$ alloy specimens nitrided at $550{ }^{\circ} \mathrm{C}(823 \mathrm{~K})$ and $r_{\mathrm{N}}=0.82 \mathrm{~atm}^{-1 / 2}$ for $(a) 15 \mathrm{~min},(b) 2 \mathrm{~h}$ and $(c) 20 \mathrm{~h}$. extensions along the ferrite grain boundaries intersecting the specimen surface (Figure 3(a)). With increasing nitriding time ( 2 hours), the thickness of both the grain boundary and the surface $\gamma^{\prime}$ layers increased, and protrusions of $\gamma^{\prime}$ developed from both the grain boundary and surface $\gamma^{\prime}$ layers (Figure 3(b)). After 20 hours of nitriding, nearly all the ferrite grain boundaries near the specimen surface were covered with the $\gamma^{\prime}$ phase, and the $\gamma^{\prime}$ protrusions had become more pronounced (Figure 3(c)). Similar observations were made from cross sections of the nitrided Fe-4.5 at. pct $\mathrm{Si}$ alloy specimens (Figure 4). In some ferrite grains a "teethlike," "comb-like" arrangement of the protrusions from the $\gamma^{\prime}$ layer is observed (Figure 5(a)), whereas at other locations a compact layer morphology is maintained (Figure 5(b)).

\section{Crystallography of Precipitation}

EBSD was performed on the cross sections of the nitrided specimens. Phase and orientation maps recorded from the 20-hours nitrided Fe-2 at. pet Si alloy specimen are shown in Figures 6(a) and (b), respectively. It follows that the grain boundary $\gamma^{\prime}$ phase, growing from any location at the original grain boundary, has different orientations at both sides of the original ferrite grain boundary. Similar observations were made for the grain boundary $\gamma^{\prime}$ phase in the 20-hours nitrided Fe-4.5 at. pct Si specimen (cf. Figure $7 \mathrm{~b}$ and d). Furthermore, for this specimen, each "tooth" of the "teeth-like" $\gamma$ ' growing into a single ferrite grain exhibits the same two (see what follows) orientations with respect to that of the ferrite grain (Figure 7(a) and (c)). Each "tooth" of the "teethlike $\gamma^{\prime \prime}$ " is composed of two $\gamma^{\prime}$ grains separated by a $\Sigma 3$ twin boundary, as determined by the EBSD analysis (Figure 8).

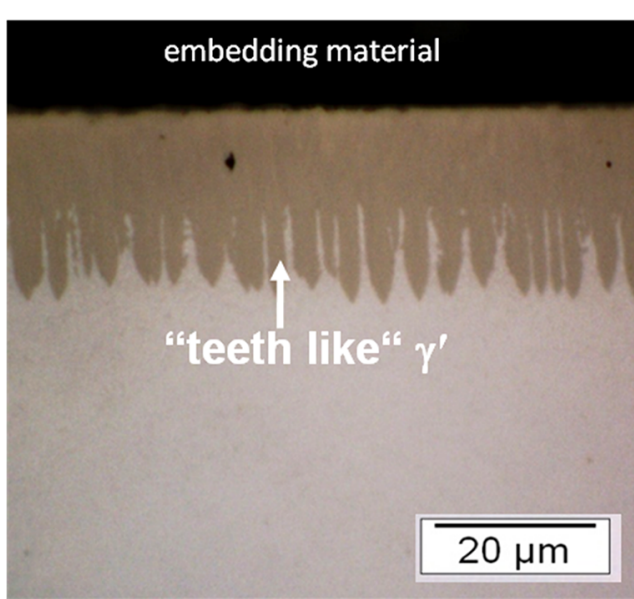

(a)

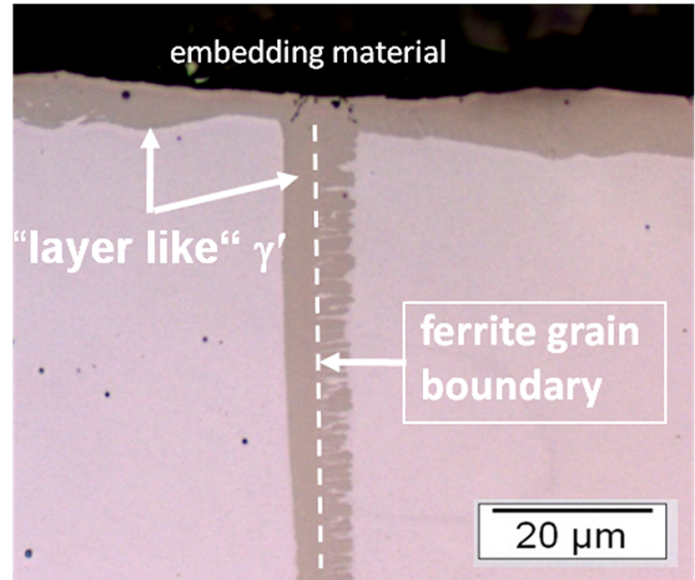

(b)

Fig. 5-Light optical micrographs recorded from cross sections of Fe-4.5 at. pct Si alloy specimens nitrided at $550{ }^{\circ} \mathrm{C}(823 \mathrm{~K})$ and $r_{\mathrm{N}}=0.82$ $\mathrm{atm}^{-1 / 2}$ for $20 \mathrm{~h}$ showing different morphologies of $\gamma^{\prime}:(a)$ "teeth-like"/"comb-like" $\gamma^{\prime}$ growing from the surface; $(b)$ layer-like $\gamma^{\prime}$ along the surface and "teeth like"/"comb like" on one side of a grain boundary and layer like on the other side of the same grain boundary. 


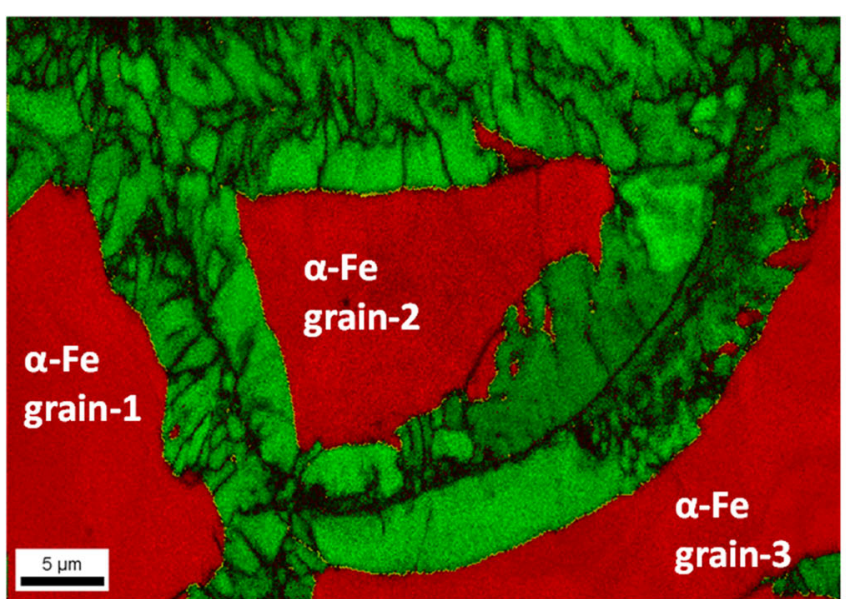

(a)
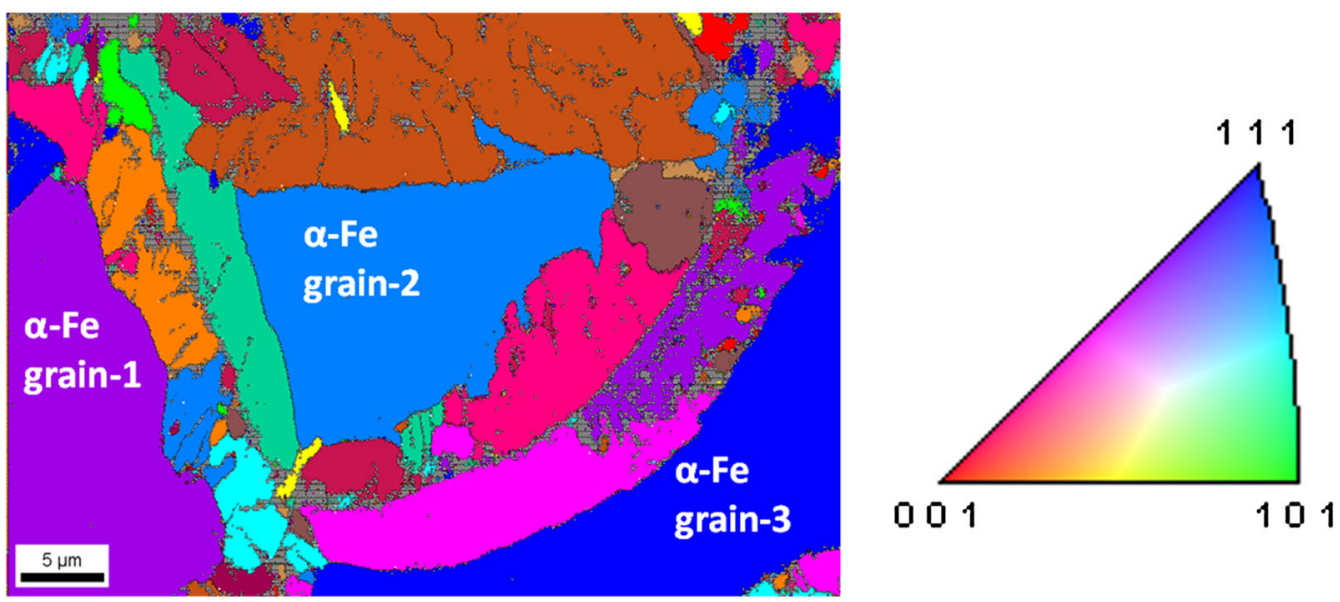

(b)

Fig. 6- (a) EBSD phase map (red: ferrite; green: $\gamma^{\prime}$ ) and $(b)$ corresponding orientation map recorded from the cross section of a Fe-2 at. pct $\mathrm{Si}$ alloy specimen nitrided for $20 \mathrm{~h}$ at $550{ }^{\circ} \mathrm{C}(823 \mathrm{~K})$ and $r_{\mathrm{N}}=0.82 \mathrm{~atm}^{-1 / 2}$ (Color figure online).

According to the procedure described in Section II-C-5, the angles between $\langle 100\rangle$ directions of ferrite and $\langle 100\rangle$ directions of $\gamma^{\prime}$ were determined. The thus obtained results for the Fe-2 at. pct Si and Fe-4.5 at. pet $\mathrm{Si}$ alloy specimens nitrided for 2 and 20 hours are shown in Figures 9 and 10, respectively. From comparison of these experimentally determined sets of angular values with those calculated theoretically for the different commonly observed ORs for FCC/BCC systems (see Table II), it follows that a (near) $\mathrm{N}-\mathrm{W}$ OR prevails for the ferrite $/ \gamma^{\prime}$ system.

At short nitriding times ( 2 hours), in both Fe-2 at. pct $\mathrm{Si}$ and $\mathrm{Fe}-4.5$ at. pct $\mathrm{Si}$ alloys for some $\gamma^{\prime}$ precipitates, occurrence of a (near) Bain OR was observed (Figures 9(a) and 10(a): see the angular data sets in the dashed rectangles and compare with Table II).

\section{Precipitation of Silicon Nitride in $\gamma^{\prime}$}

The elemental (Fe, Si, N) concentration-depth profiles, as determined by EPMA, are shown in Figures 11 and 12 for the 2- and 20-hours nitrided specimens of $\mathrm{Fe}-2$ at. pct $\mathrm{Si}$ and $\mathrm{Fe}-4.5$ at. pct $\mathrm{Si}$ alloys, respectively, superimposed on the corresponding light optical micrographs. It follows that no partitioning of $\mathrm{Si}$ had occurred: the $\mathrm{N}$ content of the $\gamma^{\prime}$ phase is higher than the $\mathrm{N}$ content expected for pure $\gamma^{\prime}-\mathrm{Fe}_{4} \mathrm{~N}$ (cf. dashed, horizontal black lines in Figures 11 and 12), which hints at the presence of silicon nitride precipitates within the $\gamma^{\prime}$. Assuming that all $\mathrm{Si}$ is present as stochiometric silicon nitride, $\mathrm{Si}_{3} \mathrm{~N}_{4}$, within the $\gamma^{\prime}-\mathrm{Fe}_{4} \mathrm{~N}$ phase (as fine precipitates), the $\mathrm{N}$ content of such a $\gamma^{\prime}-\mathrm{Fe}_{4} \mathrm{~N}+\mathrm{Si}_{3} \mathrm{~N}_{4}$ mixture can be calculated using the following Eq. [1]: 

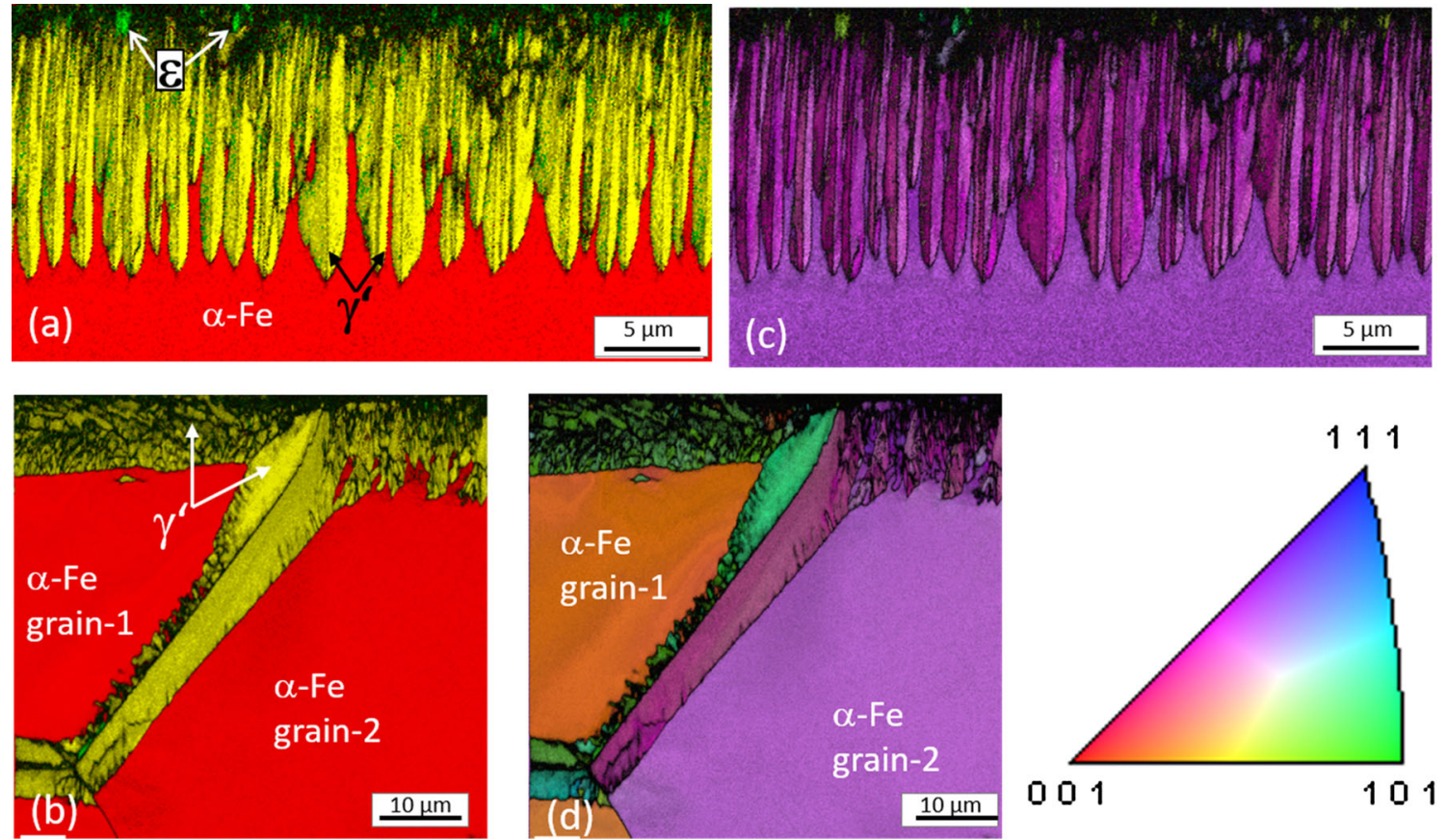

Fig. 7- (a) and (b) EBSD phase maps (red: ferrite; yellow: $\left.\gamma^{\prime}\right) ;(c)$ and $(d)$ corresponding orientation maps recorded from the cross section of a $\mathrm{Fe}-4.5$ at. pct $\mathrm{Si}$ alloy specimen nitrided for $20 \mathrm{~h}$ at $550{ }^{\circ} \mathrm{C}(823 \mathrm{~K})$ and $r_{\mathrm{N}}=0.82 \mathrm{~atm}^{-1 / 2}$. The phase map (a) demonstrates the unexpected $\varepsilon$ phase (green color) development on top of the $\gamma^{\prime}$ layer. The orientation map (c) shows that all "teeth" of the "teeth-like" $\gamma^{\prime}$ exhibit the same two twin-related orientations. The orientation of the grain boundary $\gamma^{\prime}$ phase (phase map (b)) is different at both sides of the original ferrite grain boundary in the orientation map (d) (Color figure online).

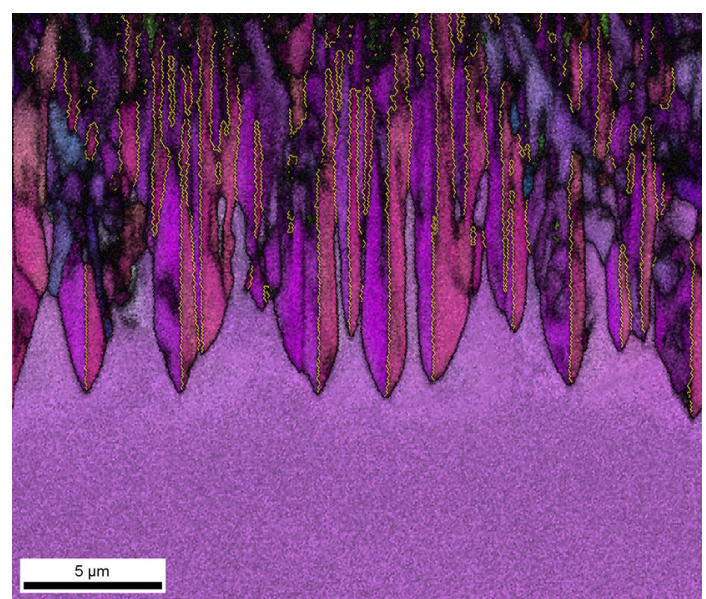

Fig. 8-EBSD orientation map recorded from the cross section of a $\mathrm{Fe}-4.5$ at. pct $\mathrm{Si}$ alloy specimen nitrided for $20 \mathrm{~h}$ at $550{ }^{\circ} \mathrm{C}(823 \mathrm{~K})$ and $r_{\mathrm{N}}=0.82 \mathrm{~atm}^{-1 / 2}$ showing the $\Sigma 3$ boundary (yellow lines) separating the two $\gamma^{\prime}$ grains of each "tooth" (see text) in a "teeth-like,"/"comb-like" part of a $\gamma^{\prime}$ layer (Color figure online).

$\mathrm{N}($ at. pct $)=\frac{4 / 3 \text { at. pct } \mathrm{Si}+1 / 4 \text { at. pct } \mathrm{Fe}}{100+4 / 3 \text { at. pct } \mathrm{Si}+1 / 4 \text { at. pct } \mathrm{Fe}} \times 100$

where "at. pct Si" and "at. pct Fe" denote the atomic percentages of $\mathrm{Si}$ and $\mathrm{Fe}$ in the un-nitrided specimen. The thus calculated theoretical $\mathrm{N}$ content together with the $\mathrm{N}$ contents determined experimentally for the $\gamma^{\prime}$ phase regions, measured by EPMA, is shown in Table III.*

*The values of the measured $\mathrm{N}$ contents presented in Table 3 are the average of at least 15 EPMA point measurements, except for the 15-min nitrided Fe-2 at. pct Si alloy specimen for which the average of three point measurements is presented. This is because thick $\gamma^{\prime}$ (which is needed for EPMA measurement with a lateral resolution of about 1 $\mu \mathrm{m}$ ) formation had occurred at only a few places along the surface of this short-time nitrided specimen. No EPMA measurements could be performed on the 15-min nitrided Fe-4.5 at. pct $\mathrm{Si}$ alloy specimen because of the extreme thinness of the $\gamma^{\prime}$ layer formed at the surface.

The theoretically predicted and the measured $\mathrm{N}$ contents agree very well (Table III) for the 2 - and 20-hours nitrided specimens, indicating that all $\mathrm{Si}$ originally present in dissolved state in the ferrite matrix has been incorporated as $\mathrm{Si}_{3} \mathrm{~N}_{4}$ within a $\gamma^{\prime}$-phase matrix. The $\mathrm{N}$ content of the developed $\gamma^{\prime}$-phase region in the 15 -min nitrided Fe-2 at. pct Si alloy (Table III) is only about 20 at. pct, which is as expected for a single-phase $\gamma^{\prime}$ region. Apparently $\gamma^{\prime}$ forms initially with all Si from the original ferrite matrix dissolved in it, and later this dissolved Si precipitates out as silicon nitride, i.e., $\gamma^{\prime}$ has a negligible solubility for $\mathrm{Si}$.

The TEM BF image and corresponding SADP recorded from the same location are shown in Figures 13(a) and (b), respectively. The BF image shows the presence of two kinds of precipitates in the $\gamma^{\prime}$ matrix: a thick irregular or nearly rectangular blocky type (shown with a white arrow in Figure 13(a)) and a platelet type (shown with a black arrow in Figure 13(a)). A DF image formed by the diffuse scattered intensity 


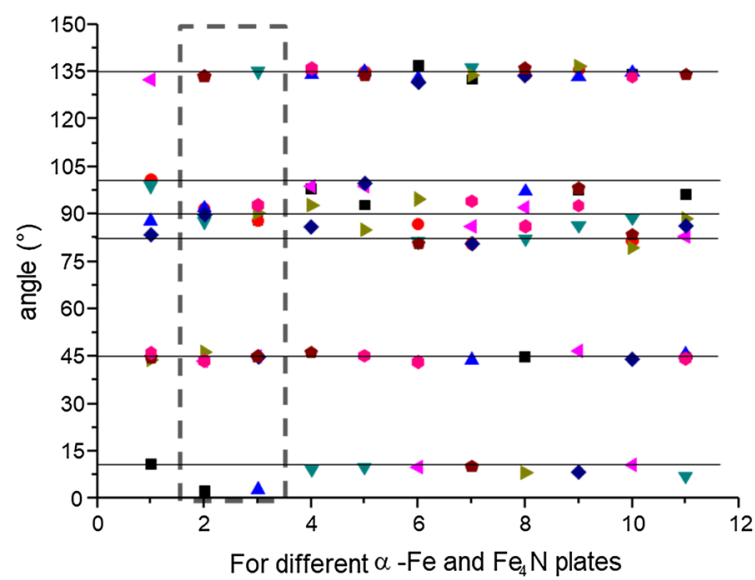

(a)

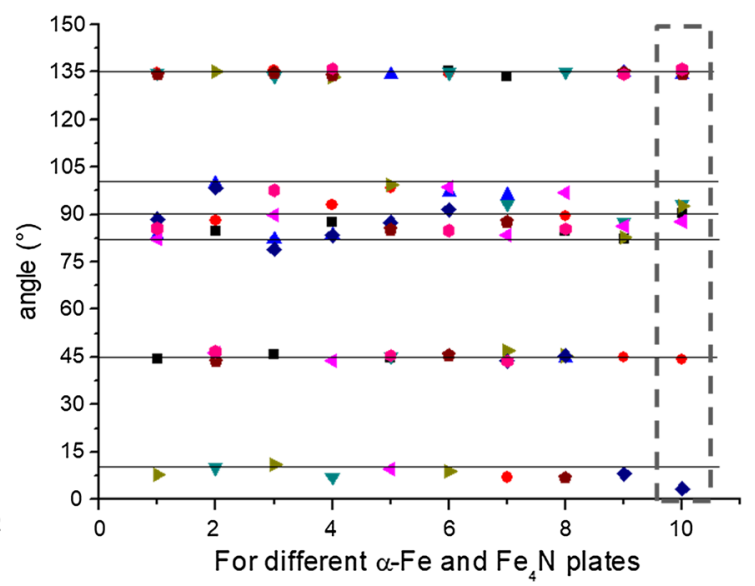

(b)

Fig. 9-Calculated angles between the $\langle 100\rangle$ directions of the ferrite matrix and the $\langle 100\rangle$ directions of the $\gamma^{\prime}$ precipitates formed in $(a)$ 2-h and (b) 20-h nitrided [at $550{ }^{\circ} \mathrm{C}(823 \mathrm{~K})$ and $r_{\mathrm{N}}=0.82 \mathrm{~atm}^{-1 / 2}$ ] Fe-2 at. pct $\mathrm{Si}$ alloy specimens. The sets of angular values closely match those expected for a (near) Nishiyama-Wassermann OR (see Table II). The angular data sets for some $\gamma^{\prime}$ precipitates as shown in the dashed rectangles suggest a (near) Bain OR.

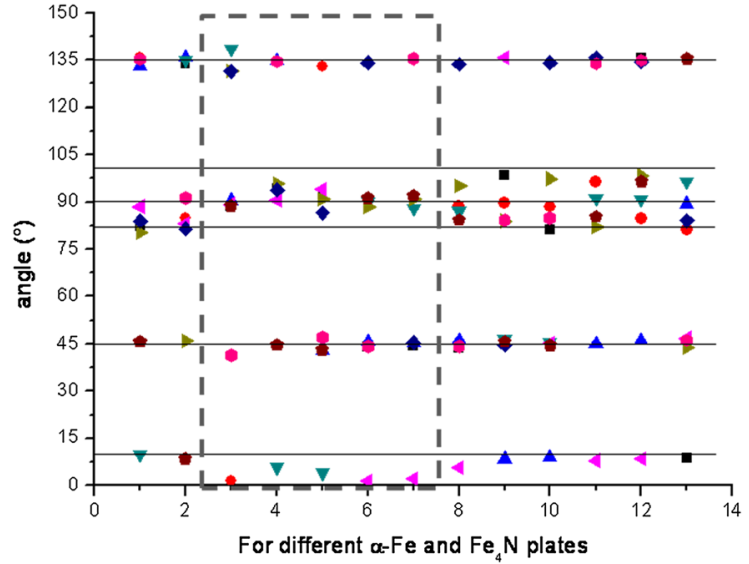

(a)

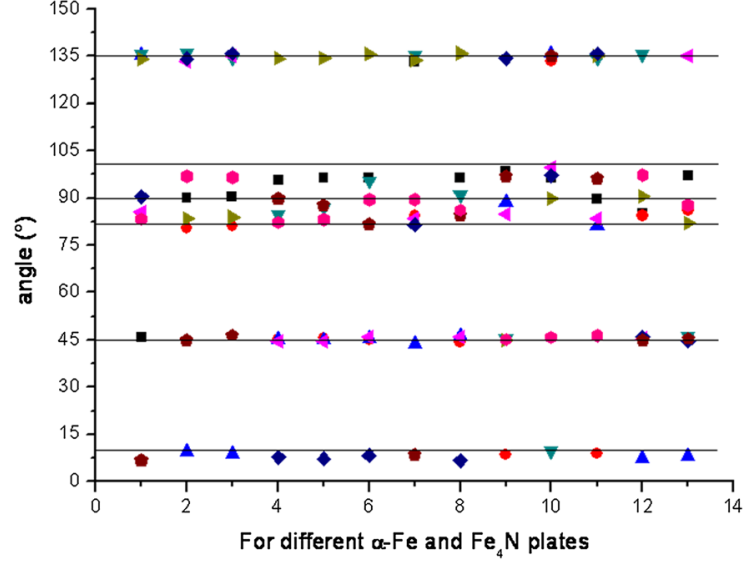

(b)

Fig. 10 - Calculated angles between the $\langle 100\rangle$ directions of the ferrite matrix and the $\langle 100\rangle$ directions of the $\gamma^{\prime}$ precipitates formed in $(a) 2$-h and (b) 20 -h nitrided [at $550{ }^{\circ} \mathrm{C}(823 \mathrm{~K})$ and $r_{\mathrm{N}}=0.82 \mathrm{~atm}^{-1 / 2}$ ] Fe-4.5 at. pct Si alloy specimens. The sets of angular values closely match those expected for a (near) Nishiyama-Wassermann OR. The angular data sets for some $\gamma^{\prime}$ precipitates as shown in the dashed rectangles suggest a (near) Bain OR.

around the transmitted 000 spot (location of the objective aperture is shown with the white dotted circle in Figure 13(b)) reveals the precipitates, observed in the $\mathrm{BF}$ image, as bright objects against a darker background (Figure 13(c)). This observation is compatible with an amorphous nature of the observed precipitates. EELS elemental analysis demonstrated the enrichment of both $\mathrm{Si}$ and $\mathrm{N}$ at the precipitate locations (Figure 14). On this basis, it is concluded that the precipitates are amorphous silicon nitride, as also observed for silicon nitrides developing in a ferrite matrix. ${ }^{[16,36]}$ It can be speculated that the platelet-type silicon nitride has possibly developed at defects as planar faults in the $\gamma$, whereas the blocky type of silicon nitride could have developed by homogeneous nucleation.

\section{E. Precipitation of Silicon Nitride in the Ferrite Matrix}

The elemental concentration-depth profiles measured on 2 and 20-hours nitrided Fe-2 at. pct $\mathrm{Si}$ alloy specimens show only a very small $\mathrm{N}$ content in the ferrite matrix underneath the $\gamma^{\prime}$ phase region. It is therefore concluded that no silicon nitride has precipitated in the diffusion zone (Figure 11: N content of ferrite is nearly zero; if all $\mathrm{Si}$ had precipitated in the ferrite matrix as $\mathrm{Si}_{3} \mathrm{~N}_{4}$, a minimum $\mathrm{N}$ content of 2.6 at. pct would be expected for the ferrite matrix). Silicon nitride precipitates only very slowly in the nitrided ferrite matrix of Fe-Si alloys. ${ }^{[26]}$ This even induces the occurrence of ideally weak nitriding kinetics. ${ }^{[16]}$ If more $\mathrm{Si}$ is dissolved initially, the driving force for silicon-nitride precipitation is larger. Indeed, whereas in the case 

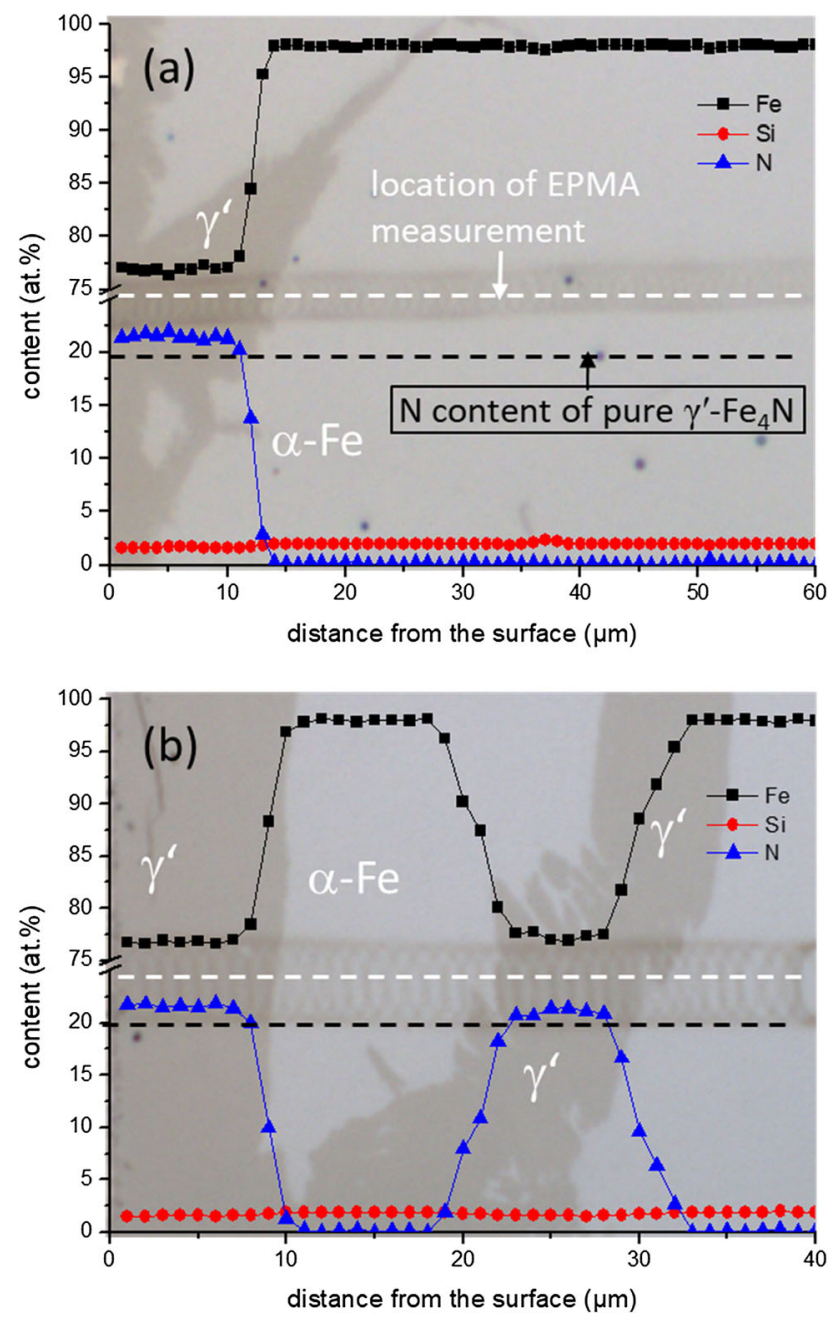

Fig. 11-Elemental ( $\mathrm{Fe}, \mathrm{Si}, \mathrm{N})$ concentration-depth profiles, as measured by EPMA, superimposed on corresponding light optical micrographs of the $(a) 2-\mathrm{h}$ and $(b) 20$-h nitrided (at $550{ }^{\circ} \mathrm{C}(823 \mathrm{~K})$ and $r_{\mathrm{N}}=0.82 \mathrm{~atm}^{-1 / 2}$ ) Fe-2 at. pct $\mathrm{Si}$ alloy specimens. The horizontal, dashed black lines represent the $\mathrm{N}$ contents expected for pure $\gamma^{\prime}$ nitride.

of Fe-4.5 at. pct Si alloy, after 2 hours of nitriding, the ferrite matrix contains a negligible amount of $\mathrm{N}$ (Figure 12(a): $\mathrm{N}$ content of ferrite is nearly zero), after 20 hours of nitriding a significant amount of $\mathrm{N}$ is detected in the ferrite matrix indicating that now the precipitation of silicon nitride has set in (Figure 12(b)).

\section{GENERAL DISCUSSION}

Iron nitride compound layers, which develop upon nitriding iron-based alloys, should incorporate alloying elements as either dissolved in them or alloying element nitride precipitates. In the case of strong nitride formers such as $\mathrm{Cr}, \mathrm{V}$ and $\mathrm{Ti}$, upon nitriding, first the alloying elements precipitate as alloying element nitrides in the ferrite matrix and later the growing $\gamma^{\prime}$ layer "overruns"
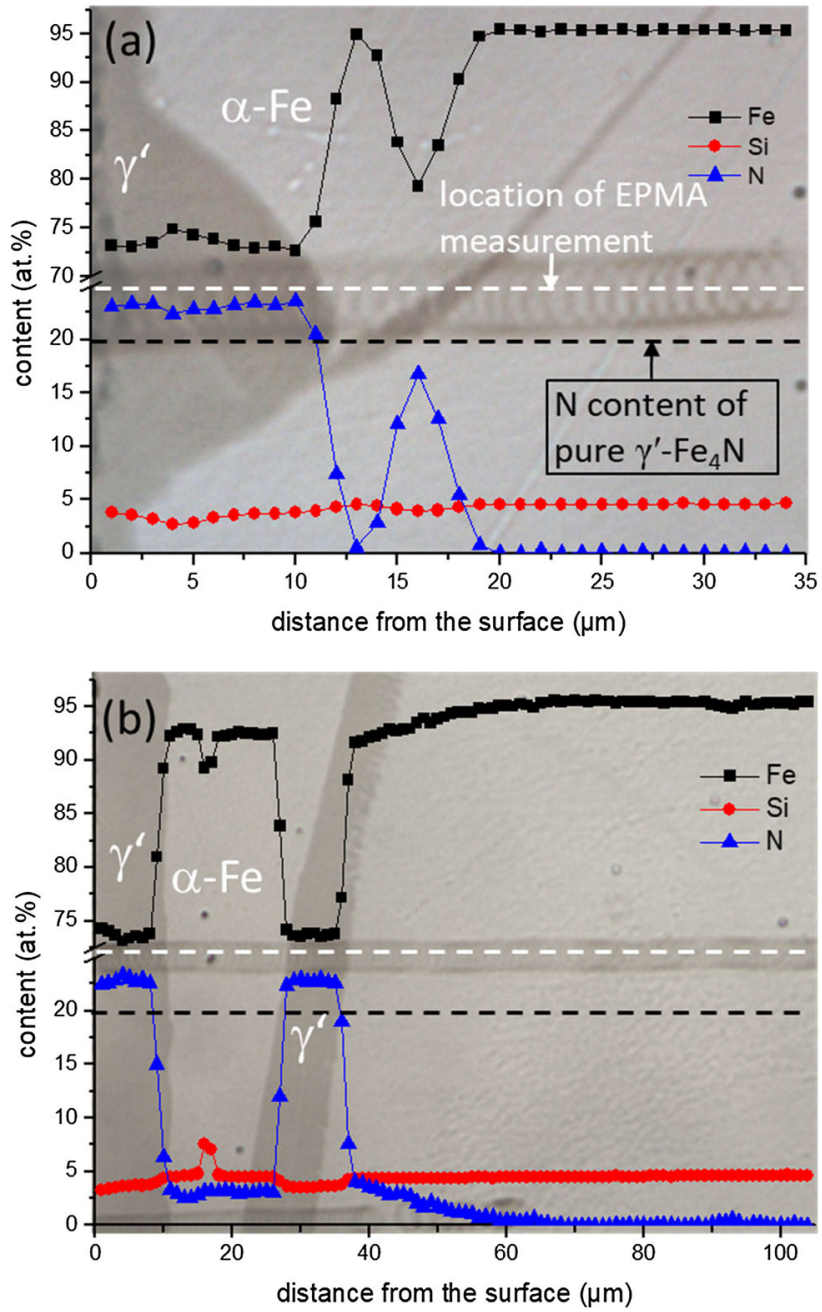

Fig. 12-Elemental ( $\mathrm{Fe}, \mathrm{Si}, \mathrm{N})$ concentration-depth profiles, as measured by EPMA, superimposed on corresponding light optical micrographs of the $(a) 2-\mathrm{h}$ and $(b) 20$-h nitrided [at $550{ }^{\circ} \mathrm{C}(823 \mathrm{~K})$ and $\left.r_{\mathrm{N}}=0.82 \mathrm{~atm}^{-1 / 2}\right] \mathrm{Fe}-4.5$ at. pct $\mathrm{Si}$ alloy specimens. The horizontal, dashed black lines represent the $\mathrm{N}$ contents expected for pure $\gamma^{\prime}$ nitride.

the alloying element nitrides, which then become incorporated in the $\gamma^{\prime}$ phase. ${ }^{[57]}$ Therefore, the influence of the strong nitride formers on the morphology of the compound layer is weak, leading to the usual layer-type growth of compound layers upon nitriding $\mathrm{Fe}-\mathrm{Cr},{ }^{[28]}$ $\mathrm{Fe}-\mathrm{V}^{[29]}$ and $\mathrm{Fe}-\mathrm{Ti}^{[30]}$ alloys.

$\mathrm{Si}$ dissolved in ferrite is effectively a weak nitride former (cf. Section I). Because of the very slow precipitation of $\mathrm{Si}_{3} \mathrm{~N}_{4}$ in ferrite (due to its large volume misfit with ferrite), nucleation of $\gamma^{\prime}$ gets delayed since the solubility of $\mathrm{Si}$ in $\gamma^{\prime}$ is very low. The difficulty in the precipitation of both alloying element nitride and $\gamma^{\prime}$ iron nitride means that a large amount of nitrogen becomes dissolved in the ferrite matrix. ${ }^{[27]}$ Eventually, such high nitrogen supersaturation induces $\gamma^{\prime}$ precipitation yet with Si dissolved in it, implying the occurrence of a state 
Table III. Theoretical Calculated N Content of the Apparent $\gamma^{\prime}$-Phase Region Supposing That All Originally Present Si Has Been Incorporated as Stoichiometric $\mathrm{Si}_{3} \mathrm{~N}_{4}$ and the Measured N Contents of the Apparent $\gamma^{\prime}$-Phase Regions After Nitriding for Different Times $\left[550{ }^{\circ} \mathrm{C}(823 \mathrm{~K})\right.$, Nitriding Potential $\left.=0.82 \mathrm{Atm}^{-1 / 2}\right]$ for Fe-2 At. Pet Si and Fe-4.5 At. Pct Si Alloys

\begin{tabular}{lcr}
\hline N Content (At. Pct) & Fe-2 At. Pct Si & Fe-4.5 At. Pct Si \\
\hline Theoretically Calculated for $\gamma^{\prime}-\mathrm{Fe}_{4} \mathrm{~N}_{\text {Plus } \mathrm{Si}_{3} \mathrm{~N}_{4} \text { Mixture }}$ & 21.36 & 23.01 \\
Measured by EPMA After Nitriding $15 \mathrm{~min}$ & $20.26 \pm 0.48$ & $23.43 \pm 0.26$ \\
Measured by EPMA After Nitriding $2 \mathrm{~h}$ & $21.35 \pm 0.26$ & $23.12 \pm 0.42$ \\
Measured by EPMA After Nitriding $20 \mathrm{~h}$ & $21.49 \pm 0.37$ & \\
\hline
\end{tabular}
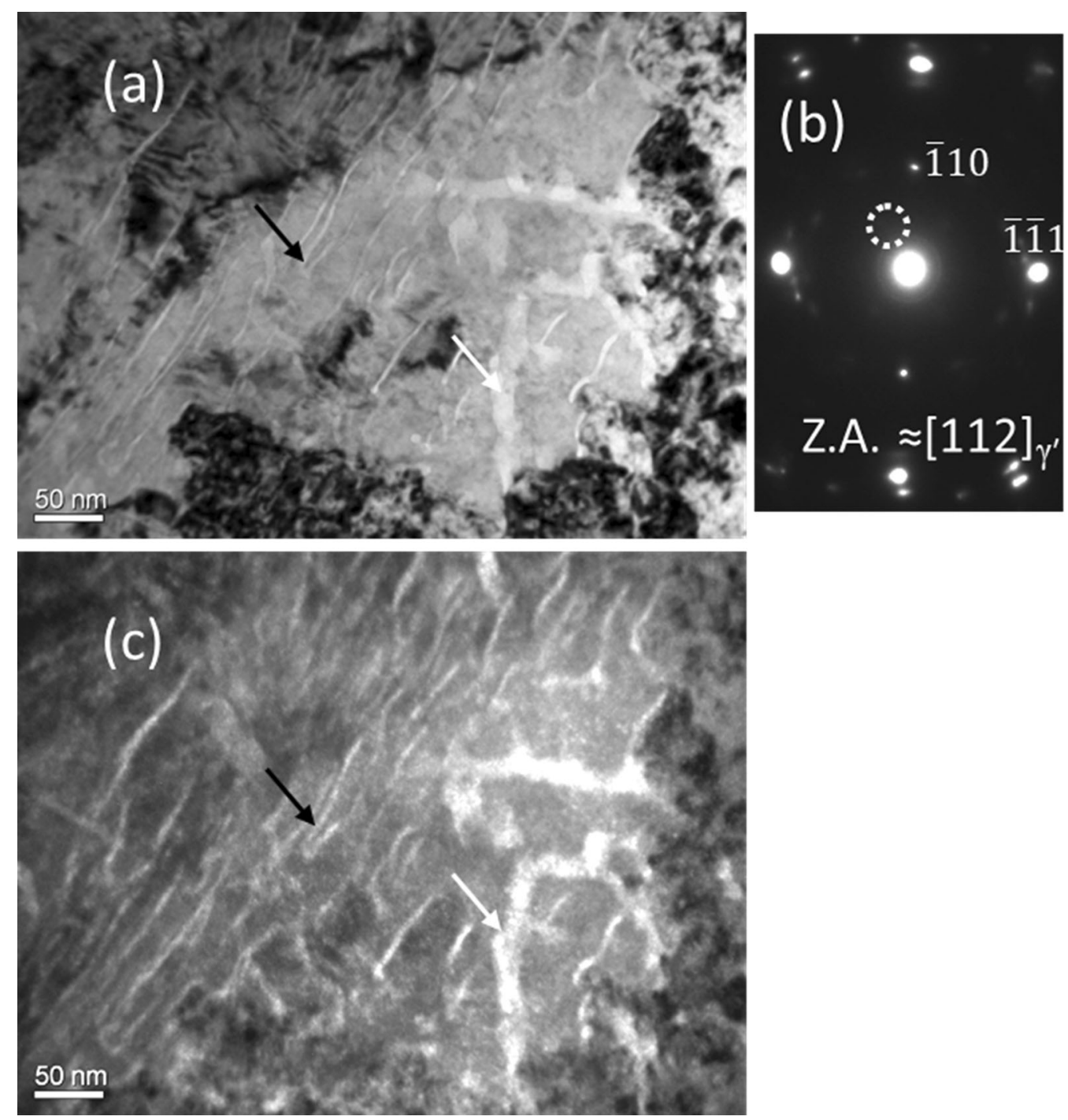

Fig. 13-TEM investigation of the Fe-4.5 at. pct Si alloy specimen nitrided for $20 \mathrm{~h}$ at $550{ }^{\circ} \mathrm{C}(823 \mathrm{~K})$ and $r_{\mathrm{N}}=0.82 \mathrm{~atm}^{-1 / 2}$. T $(a) \mathrm{BF}$ image revealing the presence of thick irregular (nearly rectangular) precipitates (see white arrow) and platelet-type precipitates (see black arrow). The corresponding SADP, with indexed $\gamma^{\prime}$ reflections (electron beam/zone axis $\approx[112] \gamma^{\prime}$ ), is shown in $(b)$. $(c)$ DF image formed with the diffuse intensity around the transmitted 000 spot (the location of the objective aperture is indicated with a white dotted circle in (b)).

of paraequilibrium. This phenomenon is similar to the effect of $\mathrm{Si}$ and $\mathrm{Al}$ on the cementite precipitation in bainitic steels ${ }^{[34,58,59]}$ : the negligible solubility of $\mathrm{Si}$ and $\mathrm{Al}$ in cementite delays or even suppresses the cementite precipitation.
Upon continuing nitriding (= annealing of the already developed $\gamma^{\prime}$ phase), the Si initially dissolved in $\gamma^{\prime}$ can release energy by precipitation as silicon nitride within the $\gamma^{\prime}$ phase. These silicon nitride precipitates developing within the $\gamma^{\prime}$ phase are amorphous (cf. 

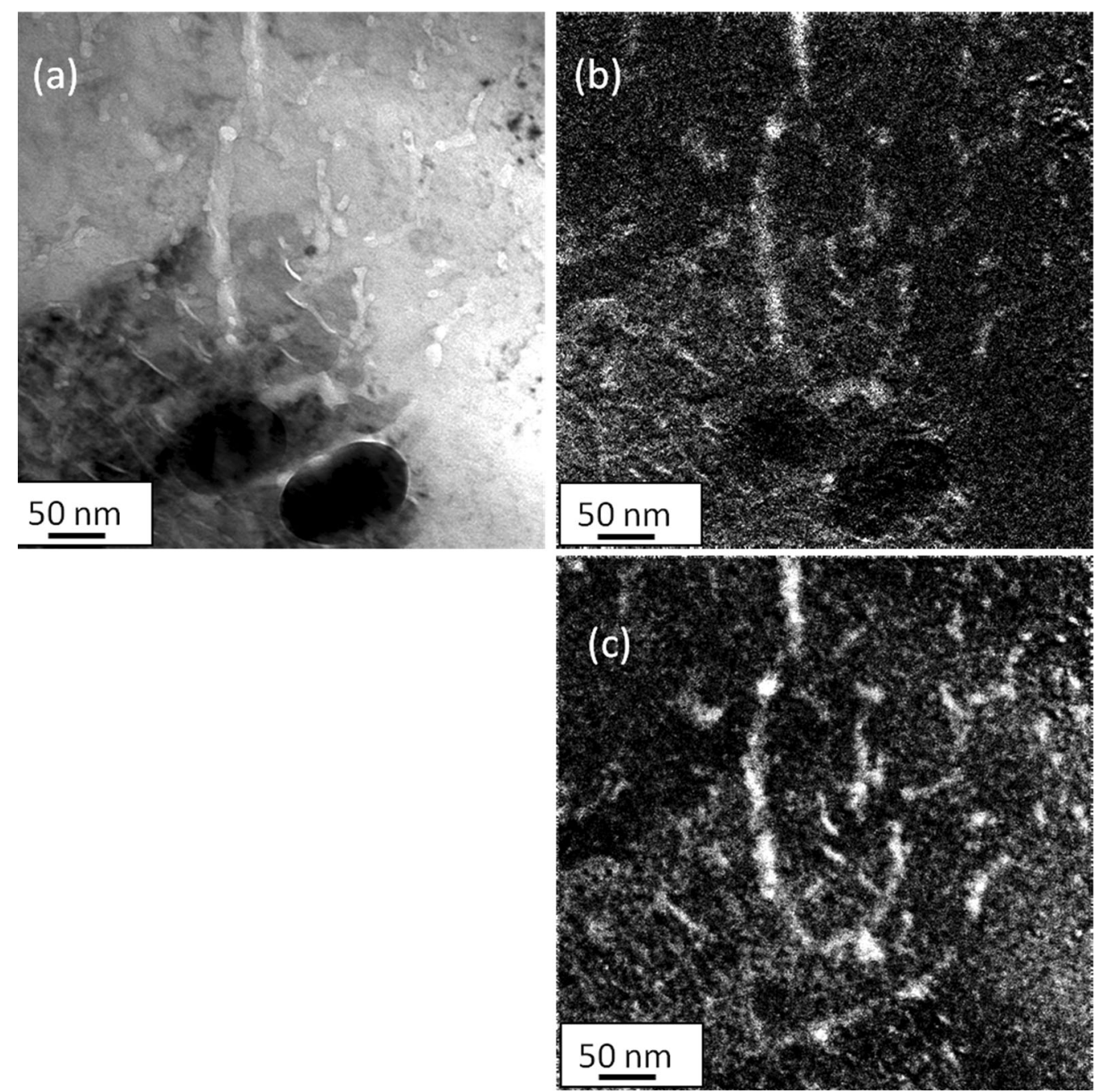

Fig. 14-For the same specimen as in Fig. 13: (a) a TEM bright-field image and the corresponding elemental maps for $(b) \mathrm{N}$ and $(c) \mathrm{Si}$, as determined by EELS

Figure 13). The thermodynamic stability of amorphous silicon nitride precipitates, compared with crystalline modification, is attributed to the lower energy of the interface between the amorphous precipitate and the crystalline matrix compared with the energy of the interface between the corresponding crystalline precipitate and the crystalline matrix. ${ }^{[36,600}$

Especially at short nitriding times, in both $\mathrm{Fe}-2$ at. pct $\mathrm{Si}$ and $\mathrm{Fe}-4.5$ at. pct $\mathrm{Si}$ alloys, for some $\gamma^{\prime}$ precipitates occurrence of a near Bain OR was observed, whereas for larger times the (near) N-W OR prevailed (cf. Section III-C). A (near) N-W OR has been reported before for the $\gamma^{\prime}$ developed in the ferrite matrix of nitrided Fe-Mo ${ }^{[33]}$ nitrided Fe-Al ${ }^{[32]}$ and a hypoeutectoid Fe-N alloy. ${ }^{[61]}$

The formation of $\gamma^{\prime}$ with a N-W OR with the ferrite matrix is associated with the occurrence of different morphologies for the $\gamma^{\prime}$ phase. This is interpreted as a consequence of the occurring orientation of the habit plane with respect to the surface or the grain boundary plane: a layer-like morphology may occur if the habit plane is (more or less) parallel to the surface or the grain boundary plane, and a plate-like morphology can occur if the habit plane is (strongly) inclined with respect to the surface or the grain boundary plane. A series of such plate-like evolutions of $\gamma^{\prime}$ phase then gives rise to the "teeth-"/"comb"-like appearance (cf. Section III-C).

It was already suggested many years ago that the formation of $\gamma^{\prime}$ in ferrite can be considered, at least partly (see what follows), as a martensitic transformation: ${ }^{[62,63]}$ a reversely running variant of the well-known $\mathrm{FCC} \rightarrow$ BCT martensitic transformation in $\mathrm{Fe}-\mathrm{C}$ and Fe-N alloys. ${ }^{[4]}$ The above restriction "partly" derives from the recognition that in ferrite a certain nitrogen supersaturation must be accomplished, at least locally, to establish a composition close to that of $\gamma^{\prime}$. Thereby, the formation of $\gamma^{\prime}$ from nitrogen ferrite upon aging also exhibits characteristics of a "nucleation and growth" reaction. In the case of the present experiments, involving gradual introduction of nitrogen in an initially nitrogen-free ferrite matrix, the nitrogen enrichment by inward diffusion from the outer atmosphere likely leads to a (more or less) laterally homogeneous enrichment of nitrogen. If the nitrogen content has surpassed a critical 
level, the formation of $\gamma^{\prime}$ may occur, more or less abruptly, in a martensitic manner as indicated above. As with the well-known FCC $\rightarrow$ BCT transformation in $\mathrm{Fe}-\mathrm{C}$ and $\mathrm{Fe}-\mathrm{N}$ alloys, a Bain lattice correspondence (involving a minimum of atomic movements) is to be expected, which, in the absence of a subsequent (lattice invariant) deformation, would mean that a Bain OR would occur. However, the shape change strived for by the transformation is so distinct (also note the large volume misfit of about 16 pet of $\gamma^{\prime}$ and ferrite) that a lattice invariant deformation is to be expected. Lattice invariant shears, parallel to the habit plane, realize the desired shape accommodation. Thereby, the occurring OR deviates from the Bain OR and becomes the NW OR.

The above discussion suggests that at a (very) initial stage of $\gamma^{\prime}$ formation the OR may be close to a Bain OR, as is observed here (cf. Section III-C). Lattice invariant shear at relatively low temperature, as in the present case (nitriding temperature is $550{ }^{\circ} \mathrm{C}$ ), can be realized, in particular, by twinning. Thus, the constitution of each "tooth" of the "teeth-/comb-like" microstructures can be understood: the two parts of a "tooth" are twin related, indeed (cf. Section III-C) separated by a $\Sigma 3$ boundary [i.e., compatible with a $\{111\} \gamma^{\prime}$ boundary plane], thereby compensating the macroscopic shape change that would occur if the martensitic transformation occurred unconstrainedly.

The unexpected formation of $\varepsilon$ nitride in the nitrided Fe-Si alloys can be discussed as follows**. A similar

\footnotetext{
**An also unexpected $\varepsilon$ formation was reported before for nitrided nanocrystalline iron, which could be interpreted as a consequence of the Gibbs-Thomson effect. ${ }^{[64]}$ This phenomenon bears no relation to the present specimens, which are not nanocrystalline.
}

unexpected formation of $\varepsilon$ was reported before for nitrided $\mathrm{Fe}-\mathrm{Al}$ alloys. ${ }^{[31]} \mathrm{As}$ both $\mathrm{Si}$ and $\mathrm{Al}$ are (effectively) weak nitride formers, the occurrence of $\varepsilon$ iron nitride could be due to a solubility of $\mathrm{Si}$ (and $\mathrm{Al}$ ) in $\varepsilon$ higher than in $\gamma^{\prime}$, which appears to show a marginal solubility of $\mathrm{Si}$ (and Al) (cf. Section III-D). In this context, it is notable that more $\varepsilon$ appears to be formed for the alloy with higher $\mathrm{Si}$ content nitrided under similar conditions compared with the alloy with lower Si content (cf. Figures 1 and 2).

\section{CONCLUSIONS}

1. $\mathrm{Si}$ acts as a weak nitride former in ferrite. $\gamma^{\prime}$ iron nitride has negligible solubility for Si. Therefore, upon nitriding Fe-Si alloy, an initially high nitrogen supersaturation of the ferrite matrix occurs. Eventually the nitrogen supersaturation becomes so large that $\gamma^{\prime}$ is forced to precipitate with Si dissolved in it. Upon continued nitriding, amorphous silicon nitride develops within $\gamma^{\prime}$.

2. The formation of $\gamma^{\prime}$ in a ferrite matrix (locally) supersaturated with nitrogen up to a composition close to that of $\gamma^{\prime}$ is of martensitic nature. Thereby, the orientation relationship (OR) between $\gamma^{\prime}$ and ferrite is initially a (near) Bain-type one transforming into a (near) Nishiyama-Wassermann type one upon growth of the $\gamma^{\prime}$. The change of OR and occurrence of twinned microstructures (as "teeth"/ "comb" like) are consequences of the accommodation of the shape change that would occur if the $\gamma^{\prime}$ formation were left unconstrained.

3. The orientation of the habit plane with respect to the surface of the specimen or the grain boundary, where the $\gamma^{\prime}$ phase can develop, governs the various occurring types of $\gamma^{\prime}$ morphology: layer like or "teeth"/"comb" like.

4. An unexpected (as incompatible with the Lehrer diagram) formation of $\varepsilon$ iron nitride occurs, because the $\varepsilon$ phase can dissolve the Si for which the $\gamma^{\prime}$ phase has negligible solubility.

\section{ACKNOWLEDGMENTS}

Open access funding provided by Projekt DEAL. The authors thank Mr. W.-D. Lang for preparation of the TEM specimens, Mr P. Kress for assistance with the nitriding experiments and Mrs. S. Haug for assistance with the EPMA experiments (all with Max Planck Institute for Intelligent Systems).

\section{OPEN ACCESS}

This article is licensed under a Creative Commons Attribution 4.0 International License, which permits use, sharing, adaptation, distribution and reproduction in any medium or format, as long as you give appropriate credit to the original author(s) and the source, provide a link to the Creative Commons licence, and indicate if changes were made. The images or other third party material in this article are included in the article's Creative Commons licence, unless indicated otherwise in a credit line to the material. If material is not included in the article's Creative Commons licence and your intended use is not permitted by statutory regulation or exceeds the permitted use, you will need to obtain permission directly from the copyright holder. To view a copy of this licence, visit http://creat ivecommons.org/licenses/by/4.0/.

\section{REFERENCES}

1. Source Book on Nitriding, 2nd ed., P.M. Unterweiser, and A.G. Gray, eds., Source Book on Nitriding, ASM, Metals Park, $\mathrm{OH}, 1977$.

2. Arbeitsgemeinschaft Wärmebehandlung und Werkstofftechnik e.V., AWT-Tagung Nitrieren und Nitrocarburieren, 2nd ed., E.J. Mittemeijer, and J. Grosch, eds., Arbeitsgemeinschaft Wärmebehandlung und Werkstofftechnik e.V., AWT-Tagung Nitrieren und Nitrocarburieren, AWT-Bremen, Wiesbaden, 1991.

3. C.H. Knerr, T.C. Rose, J.H. Filkowski:. ASM Handbook, Heat Treating, vol. 4, G.M. Davidson, S.R. Lampman, T.B. Zorc, J.L. 
Daquila, A.W. Ronke, K.L. Henninger, R.C. Uhl and J.R. Davis, eds., ASM International, Metals Park, OH, 1991, pp. 387-409.

4. European Conference on Heat Treatment 2010 - Nitriding and Nitrocarburising, 2nd ed., F. Hoffmann, and H. Klümper-Westkamp, eds., European Conference on Heat Treatment 2010 - Nitriding and Nitrocarburising, AWT-Bremen, Aachen, 2010.

5. E.J. Mittemeijer: ASM Handbook 4A: Steel Heat Treating Fundamentals and Processes, J. Dossett and G.E. Totten, eds., ASM International, Metals Park, 2013, pp. 619-46.

6. Thermochemical Surface Engineering of Steels, 2nd ed., E.J. Mittemeijer, and M.A.J. Somers, eds., Thermochemical Surface Engineering of Steels, Woodhead Publishing, Sawston, 2015.

7. A. Machlet: US Patent No. 1065379, 1913.

8. M.H. Biglari, C.M. Brakman, and E.J. Mittemeijer: Philos. Mag. A, 1995, vol. 72, pp. 1281-99.

9. H.H. Podgurski and H.E. Knechtel: Trans Metall Soc AIME, 1969, vol. 245, pp. 1595-602.

10. S.R. Meka, S.S. Hosmani, A.R. Clauss, and E.J. Mittemeijer: Int. J. Mater. Res., 2008, vol. 99, pp. 808-14.

11. S.R. Meka, E. Bischoff, S.S. Hosmani, and E.J. Mittemeijer: Int. J. Mater. Res., 2014, vol. 105, pp. 1057-66.

12. Y. Tomio, S. Kitsuya, K. Oh-ishi, K. Hono, G. Miyamoto, and T. Furuhara: Metall. Mater. Trans. A, 2014, vol. 45A, pp. 239-49.

13. R.E. Schacherl, P.C.J. Graat, and E.J. Mittemeijer: Metall. Mater. Trans. A, 2004, vol. 35A, pp. 3387-98.

14. B. Mortimer, P. Grieveson, and K.H. Jack: Scan. J. Metall., 1972, vol. 1, pp. 203-09.

15. S.R. Meka, E. Bischoff, B. Rheingans, and E.J. Mittemeijer: Philos. Mag. Lett., 2013, vol. 93, pp. 238-45.

16. S.R. Meka, K.S. Jung, E. Bischoff, and E.J. Mittemeijer: Philos. Mag., 2012, vol. 32, pp. 1435-55.

17. R.M. Lankreijer, M.A.J. Somers and E.J. Mittemeijer: Proceedings of the International Conference on High Nitrogen Steels, J. Foct and A. Hendry, eds., Institute of Metals, London, 1989. p. 108.

18. H.P. van Landeghem, M. Gouné, S. Bordère, F. Danoix, and A. Redjaïmia: Acta Mater., 2015, vol. 93, pp. 218-34.

19. H.P. van Landeghem, M. Goune, and A. Redjaimia: Steel Res. Int., 2012, vol. 83, pp. 590-93.

20. H.P. van Landeghem, M. Gouné, T. Epicier, and A. Redjaïmia: Scripta Mater., 2013, vol. 68, pp. 187-90.

21. S.S. Hosmani, R.E. Schacherl, and E.J. Mittemeijer: Acta Mater., 2006, vol. 54, pp. 2783-92.

22. J.D. Kamminga and G.C.A.M. Janssen: Surf. Coat. Technol., 2005, vol. 200, pp. 909-12.

23. P.C. Vanwiggen, H.C.F. Rozendaal, and E.J. Mittemeijer: $J$. Mater. Sci., 1985, vol. 20, pp. 4561-82.

24. A.R. Clauss, E. Bischoff, S.S. Hosmani, R.E. Schacherl, and E.J. Mittemeijer: Metall. Mater. Trans. A, 2009, vol. 40A, pp. 1923-34.

25. K.S. Jung, S.R. Meka, R.E. Schacherl, E. Bischoff, and E.J. Mittemeijer: Metall. Mater. Trans. A, 2012, vol. 43A, pp. 934 44.

26. B. Schwarz, S.R. Meka, R.E. Schacherl, E. Bischoff, and E.J. Mittemeijer: Acta Mater., 2014, vol. 76, pp. 394-403.

27. S.R. Meka and E.J. Mittemeijer: JOM, 2013, vol. 65, pp. 769-75.

28. S.S. Hosmani, R.E. Schacherl, and E.J. Mittemeijer: Int. J. Mater. Res., 2006, vol. 97, pp. 1545-49.

29. S.S. Hosmani, R.E. Schacherl, and E.J. Mittemeijer: J. Mater. Sci., 2009, vol. 44, pp. 520-27.

30. H. Miyamura, J. Takada, H. Kuwahara, and S. Kikuchi: J. Mater. Sci., 1986, vol. 21, pp. 2514-18.

31. S.R. Meka, E. Bischoff, R.E. Schacherl, and E.J. Mittemeijer: Philos. Mag., 2012, vol. 92, pp. 1083-1105.

32. S. Meka, R.E. Schacherl, E. Bischoff, and E.J. Mittemeijer: $A d v$. Mater. Res., 2009, vols. 89-91, pp. 371-76.
33. H. Selg, E. Bischoff, I. Bernstein, T. Woehrle, S.R. Meka, R.E. Schacherl, T. Waldenmaier, and E.J. Mittemeijer: Philos. Mag., 2013, vol. 93, pp. 2133-60.

34. H.K.D.H. Bhadeshia: Bainite in Steels, Institute of Materials, London, 2001.

35. C.C. Liao and C.K. Hou: J. Mag. Mater, 2010, vol. 322, pp. 434-42.

36. E.J. Mittemeijer, M.H. Biglari, A.J. Bottger, N.M. van der Pers, W.G. Sloof, and F.D. Tichelaar: Scripta Mater., 1999, vol. 41, pp. $625-30$.

37. M.H. Biglari, C.M. Brakman, M.A.J. Somers, W.G. Sloof, and E.J. Mittemeijer: Z. Metall., 1993, vol. 84, pp. 124-31.

38. T. Steiner and E.J. Mittemeijer: J. Mater. Eng. Perf., 2016, vol. 25, pp. 2091-2102.

39. K.N. Sasidhar and S.R. Meka: Acta Mater., 2018, vol. 161, pp. 266-72.

40. K.N. Sasidhar and S.R. Meka: Philos. Mag., 2019, vol. 99, pp. 2152-68.

41. H. Atmani and O. Thoumire: Mater. Sci. B, 2002, vol. 25, pp. 219-25.

42. T. Takase, Y. Nakamura, and M. Sumitomo: J Jpn Inst Met Mater, 1976, vol. 40, pp. 663-69.

43. V.A. Fedchun and N.V. Silina: Met. Sci. Heat Treat., 1988, vol. 30, pp. 890-95.

44. E.J. Mittemeijer: Fundamentals of Materials Science, Springer, Berlin, 2010.

45. E.J. Mittemeijer and M.A.J. Somers: Surf. Eng., 1997, vol. 13, pp. 483-97.

46. E.J. Mittemeijer and J.T. Slycke: Surf. Eng., 1996, vol. 12, pp. $152-62$.

47. E. Lehrer: Z. Elektrochem. Angew. Phys. Chem, 1930, vol. 36, p. 383.

48. J.L. Pouchou and F. Pichoir: Rech Aerosp., 1984, vol. 3, pp. 167-92.

49. ICDD. International Centre for Diffraction Data, PDF-2, 2002.

50. U. Dahmen: Acta Metall., 1982, vol. 30, pp. 63-73.

51. W.Z. Zhang and G.C. Weatherly: Prog. Mater Sci., 2005, vol. 50, pp. 181-292.

52. E.C. Bain: Trans. Am. Inst. Min. Met. Eng., 1924, vol. 70, pp. 25-46.

53. W. Pitsch and A. Scharader: Arch. Eisenhuettenwesen, 1958, vol. 29, pp. 715-21.

54. Z. Nishiyama: Sci. Rep. Tohoku Imp. Univ., 1934, vol. 23, pp. 637-64.

55. G. Wassermann: Arch. Eisenhiittenwesen, 1933, vol. 6, pp. 347-51.

56. G. Kurdjumow and G. Sachs: Z. Phys. A, 1930, vol. 64, pp. $325-43$.

57. S.S. Hosmani, R.E. Schacherl, and E.J. Mittemeijer: HTM J. Heat Treat. Mater., 2008, vol. 63, pp. 139-46.

58. H.K.D.H. Bhadeshia and J.W. Christian: Metall. Trans. A, 1990, vol. 21A, pp. 767-97.

59. E. Kozeschnik and H.K.D.H. Bhadeshia: Mater. Sci. Technol., 2008, vol. 24, pp. 343-47.

60. L.P.H. Jeurgens, Z.M. Wang, and E.J. Mittemeijer: Int. J. Mater. Res., 2009, vol. 100, pp. 1281-1307.

61. X.C. Xiong, A. Redjaimia, and M. Goune: J. Mater. Sci., 2009, vol. 44 , pp. $632-38$.

62. H.M. Otte and T.B. Massalski: Acta Metall., 1958, vol. 6, pp. 494-99.

63. W. Pitsch: Arch. Eisenhutte, 1960, vol. 32, pp. 573-79.

64. M. Wohlschlogel, U. Welzel, and E.J. Mittemeijer: Appl. Phys. Lett., 2007, vol. 91, p. 141901.

Publisher's Note Springer Nature remains neutral with regard to jurisdictional claims in published maps and institutional affiliations. 